\title{
Pemberdayaan Ekonomi Kreatif di Desa Sukaresmi melalui Daur Ulang Plastik Kresek menjadi Hiasan yang Bernilai Ekonomi
}

\author{
Kuwat Riyanto $^{\text {1) }}$ | Lisa Kustina ${ }^{2)}$ | Fathurohman $^{\text {3) }}$ \\ 1,2,3) Universitas Pelita Bangsa \\ kuwat.riyanto@pelitabangsa.ac.id | lisakustina@pelitabangsa.ac.id | \\ fathur.eng@pelitabangsa.ac.id
}

\begin{abstract}
Abstrak: Limbah plastik sangat mencemari lingkungan. Keterlibatan masyarakat dalam mengurangi pemakaian plastik dan mendaur ulang plastik masih sangat minim. Besarnya dampak negatif limbah plastik terhadap lingkungan, sehingga dibutuhkan proses daur ulang. Salah satunya melalui daur ulang plastik kresek. Kreatifitas pengelolaan limbah dapat mengurangi dampak negatif pencemaran lingkungan serta meningkatkan kesadaran masyarakat akan pentingnya menjaga lingkungan dan memanfaatkan setiap hal, baik itu limbah maupun barang yang tidak terpakai menjadi barang yang bernilai ekonomi. Kreatifitas mengubah limbah yang tidak bernilai dapat diolah menjadi sesuatu yang bernilai. Sampah plastik kresek yang tidak bernilai dapat diolah menjadi hiasan bunga cantik yang memiliki nilai ekonomi. Hal ini sebagai wujud tanggungjawab dan pengabdian kepada masyarakat serta untuk menjaga lingkungan khususnya Desa Sukaresmi terhadap banyaknya limbah sampah plastik kresek diwilayah tersebut. Tujuan dari kegiatan pengabdian ini adalah untuk meningkatkan keterampilan masyarakat khususnya Desa Sukaresmi untuk memanfaatkan limbah plastik kresek menjadi hiasan yang bernilai ekonomi, sehingga dapat meningkatkan penghasilan masyarakat serta mengurangi limbah plastik kresek. Kegiatan ekonomi kreatif melalui daur ulang plastik kresek ini menggunakan metode pendekatan kepada masyarakat melalui sosialisasi bahwa setiap limbah apabila diolah dengan baik akan menghasilkan barang yang bernilai ekonomi. Masyarakat Desa Sukaresmi diharapkan mampu mengolah limbah plastik kresek menjadi barang yang bernilai ekonomi. Limbah plastik kresek tersebut dapat diolah menjadi hiasan bunga cantik yang bernilai ekonomi.
\end{abstract}

Kata Kunci: Pemberdayaan; Ekonomi Kreatif; Daur Ulang; Plastik Kresek; Hiasan

\section{Pendahuluan}

Desa Sukaresmi terletak di wilayah Cikarang bagian selatan yang lokasinya tidak jauh dari pusat keramaian karena desa tersebut berdekatan dengan Mall Lippo Cikarang serta Kawasan Industri Hyundai. Masyarakat asli Cikarang mayoritas bekerja di perusahaanperusahaan di sekitar Cikarang. Kawasan ini sebenarnya cukup potensial untuk mengembangkan industri kreatif. Lokasi yang strategis serta peluang usaha yang menjanjikan merupakan kunci untuk mengembangkan ekonomi kreatif.

Masalah yang dihadapi masyarakat Cikarang khususnya Desa Sukaresmi saat ini adalah semakin banyaknya limbah plastik, salah satunya plastik kresek. Setiap membeli makanan, barang, ataupun pakaian dan lainnya selalu dibungkus dengan plastik, yang pada akhirnya hanya dibuang begitu saja. Padahal limbah plastik merupakan limbah yang sulit untuk terurai karena membutuhkan waktu 100 hingga 500 tahun untuk bisa terurai dengan sempurna (Hardianti, Abas, \& Ningsih, 2017). Limbah plastik sangat mencemari lingkungan. Karena terlalu banyaknya dampak negatif limbah tersebut maka dibutuhkan daur ulang plastik kresek 
bekas menjadi sesuatu yang bernilai sehingga dapat menambah pendapatan masyarakat serta mengurangi dampak negatif terhadap lingkungan. Saat ini masyarakat Desa Sukaresmi hanya membuang sampah plastik kresek begitu selesai digunakan. Sampah tersebut hanya ditampung sementara selanjutnya truk-truk sampah akan mengangkutnya untuk dibuang begitu saja di tempat penampungan sampah. Sejauh ini keterlibatan masyarakat dalam mengurangi pemakaian dan mendaur ulang plastik masih sangat minim. Biasanya plastik dibakar untuk memusnahkannya dari pandangan. Padahal, jika pembakaran plastik tidak sempurna (di bawah $800^{\circ} \mathrm{C}$ ) dapat membentuk dioksin, yaitu senyawa yang dapat memicu kanker, hepatitis, pembengkakan hati dan gangguan system saraf (Sirait, 2009).

Pengelolaan limbah organik maupun non organik yang tidak berbahaya dapat disosialisasikan menjadi produk baru yang memiliki nilai ekonomi tinggi (Angraeni, Kamara, \& Dahlan, 2012). Pengolahan limbah plastik kresek menjadi hiasan bunga cantik dapat meningkatkan pendapatan masyarakat Desa Sukaresmi. Kreatifitas pengelolaan limbah dapat mengurangi dampak negatif pencemaran lingkungan serta kesadaran masyarakat akan pentingnya menjaga lingkungan dan memanfaatkan setiap hal, baik itu limbah maupun barang yang tidak terpakai menjadi barang yang bernilai ekonomi. Daur ulang adalah salah satu strategi pengelolaan sampah padat yang terdiri atas kegiatan pemisahan, pengumpulan, pemrosesan, pendistribusian, dan pembuatan produk atau material bekas pakai dan komponen utama dalam menajemen sampah modern (Permadi, 2011).

Sampah adalah suatu bahan yang terbuang atau dibuang dari sumber hasil aktifitas manusia maupun alam yang belum memiliki nilai ekonomis. Sampah digolongkan menjadi dua berdasarkan sumbernya, yaitu pertama berasal dari aktivitas kehidupan (rumah tangga) dan yang kedua berasal dari aktivitas bisnis (Sucipto, 2012). Sampah padat dapat di daur ulang dengan cara memisahkan, mengumpulkan, memproses, mendistribusi dan membuatnya menjadi barang-barang yang dapat digunakan kembali. Sampah padat juga menjadi bahan utama dalam proses daur ulang. Sampah dapat mencemari lingkungan dan mambahayakan kesehatan. Sampah juga menyebabkan timbulnya banjir. Akan tetapi, melalui daur ulang, sampah dapat diolah lagi menjadi barang yang berguna. Daur ulang sampah adalah proses pengolahan kembali barang-barang yang tidak berguna menjadi barang yang berguna.

Sampah plastik dikategorikan menjadi dua sampah plastik yang memiliki nilai seperti botol plastik dan sampah plastik yang tidak memiliki nilai seperti plastik kresek (Putra, Yuliana, \& Rahayu, 2012). Sampah plastik kresek yang tidak bernilai dapat diolah menjadi hiasan bunga cantik yang memiliki nilai ekonomi. Dengan kreatifitas mahasiswa Universitas Pelita Bangsa, setiap limbah yang tidak bernilai dapat diolah menjadi sesuatu yang bernilai. Hal ini sebagai wujud tanggungjawab dan pengabdian kepada masyarakat serta untuk menjaga lingkungan khususnya Desa Sukaresmi terhadap banyaknya limbah sampah plastik kresek diwilayah tersebut. Dengan konsep Reuse-Reduce-Recycle, sampah plastik kresek dapat dibuat menjadi hiasan bunga cantik yang bernilai ekonomi.

\section{Realisasi Kegiatan}

Sampah merupakan masalah yang selalu dihadapi oleh semua negara baik negara maju ataupun negara berkembang seperti Indonesia. Setiap tahun penggunaan sampah plastik di Indonesia terus meningkat. Pemerintah, organisasi lingkungan serta instansi-instansi Pendidikan saling bekerjasama untuk menurunkan dampak negatif dari sampah. Beberapa hal yang dilakukan diantaranya membentuk bank sampah, pengomposan komunal, dan daur ulang sampah plastik untuk meningkatkan kesehatan masyarakat, meningkatkan kualitas lingkungan serta menjadikan sampah sebagai sumber daya sesuai dengan tujuan dari penyelenggaraan pengelolaan sampah yang diatur dalam Undang-Undang No. 18 tahun 2008 (Mahyudin, 2017). 
Pengolahan sampah di Desa Sukaresmi belum terorganisir dengan baik. Sampah pada dasarnya hanya ditaruh ditempat sampah kemudian nantinya akan diambil oleh truk-truk pengangkut sampah yang nantinya akan dibuang ke tempat pembuangan akhir. Masyarakat Desa Sukaresmi pun belum sadar bahwa pada dasarnya sampah merupakan sumber daya yang dapat dimanfaatkan dan memiliki nilai ekonomi yang tinggi.

Keterbatasan pemerintah kota dalam menanggulangi sampah harusnya ditunjang oleh upaya dan kesadaran masyarakat untuk mengurangi jumlah sampah yang ada (Linda, 2016). Karena kesadaran masyarakat Desa Sukaresmi masih rendah mengenai daur ulang sampah, oleh karena itu kegiatan pengabdian Universitas Pelita Bangsa melakukan sosialisasi kepada masyarakat serta melakukan pelatihan daur ulang sampah menjadi hiasan bunga plastik yang bernilai ekonomi. Di bawah ini adalah salah satu contoh hiasan bunga plastik yang berasal dari limbah plastik bekas yang memiliki nilai jual tinggi.

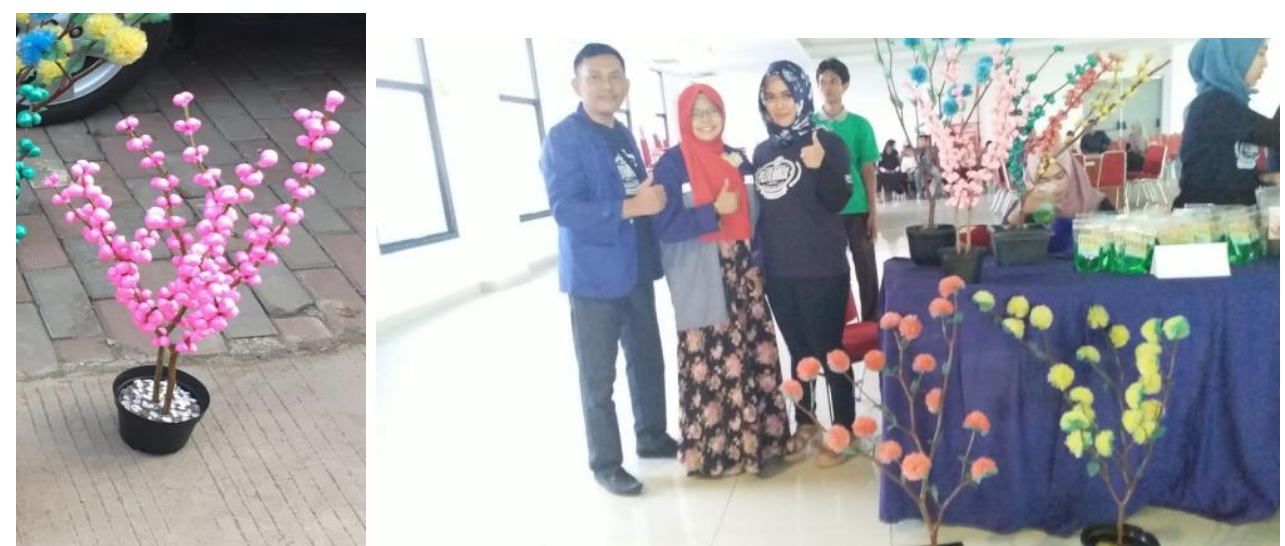

Gambar 1. Pelaksanaan daur ulang plastik bekas

Bahan yang diperlukan untuk membuat satu hiasan bunga cantik adalah kantong plastik bekas, warna kuning, merah, dan putih (warna apapun pada prinsipnya boleh) untuk membuat mahkota (kelopak) bunga, kantong plastik warna hijau untuk penutup tangkai bunga, kawat ukuran sedang untuk tangkai bunga, kertas karton untuk pola lingkaran, spidol atau pensil untuk menggambar pola lingkaran pada kertas karton, gunting, korek gas atau lilin untuk membakar kantong plastik saat membuat mahkota bunga, tang untuk memotong dan melekukkan kawat, binder clip (penjepit kertas untuk memegang lembaran-lembaran kantong kresek agar tidak bergeser saat digunting).

Cara pembuatannya pun cukup simple pertama membuat sebuah pola dari kertas karton dibentuk lingkaran dengan diameter $14 \mathrm{~cm}$. letakan kantong plastik bekas di atas lantai kemudian dirapikan. Selanjutnya membuat pola berbentuk lingkaran dari kertas karton atau kertas yang agak tebal. Selanjutnya Gunting ujung atas dan ujung bawah kantong plastik membentuk persegi untuk memudahkan saat melipat kantong kresek pada langkah berikutnya. Kemudian Lipat-lipat kantong plastik sehingga cukup besar dan muat jika ditaruh pola lingkaran di atasnya. 


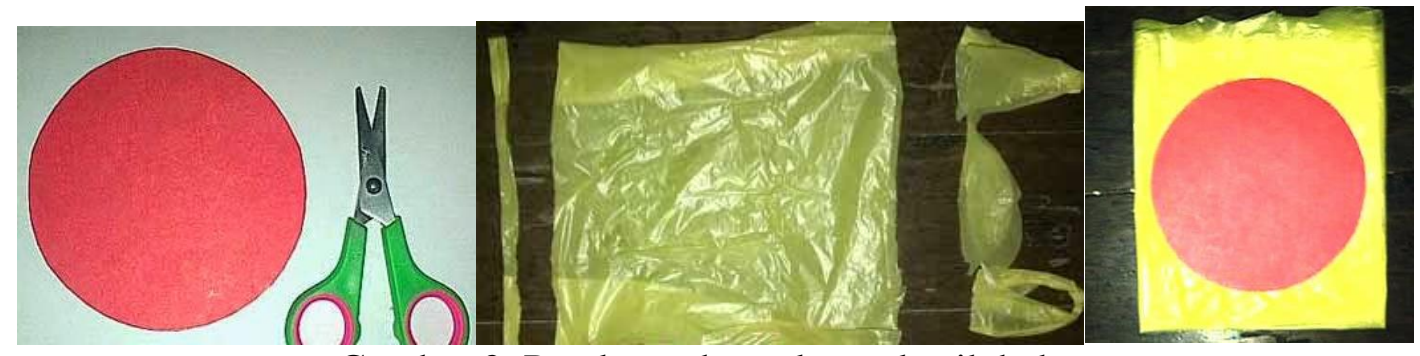

Gambar 2. Peralatan daur ulang plastik bekas

Supaya tidak mudah bergeser jepit sisi sisi kantong plastik. Kemudian gunting kantong plastik sesuai pola lingkaran. Selanjutnya plastic kresek bekas membuatnya menjadi mahkota bunga dahlia. Caranya, dengan melipat-lipat lingkaran (4 kali lipatan). Kemudian gunting ujung lipatan seperti ditunjukkan gambar, untuk membentuk pinggiran mahkota bunga yang berlekuk-lekuk.

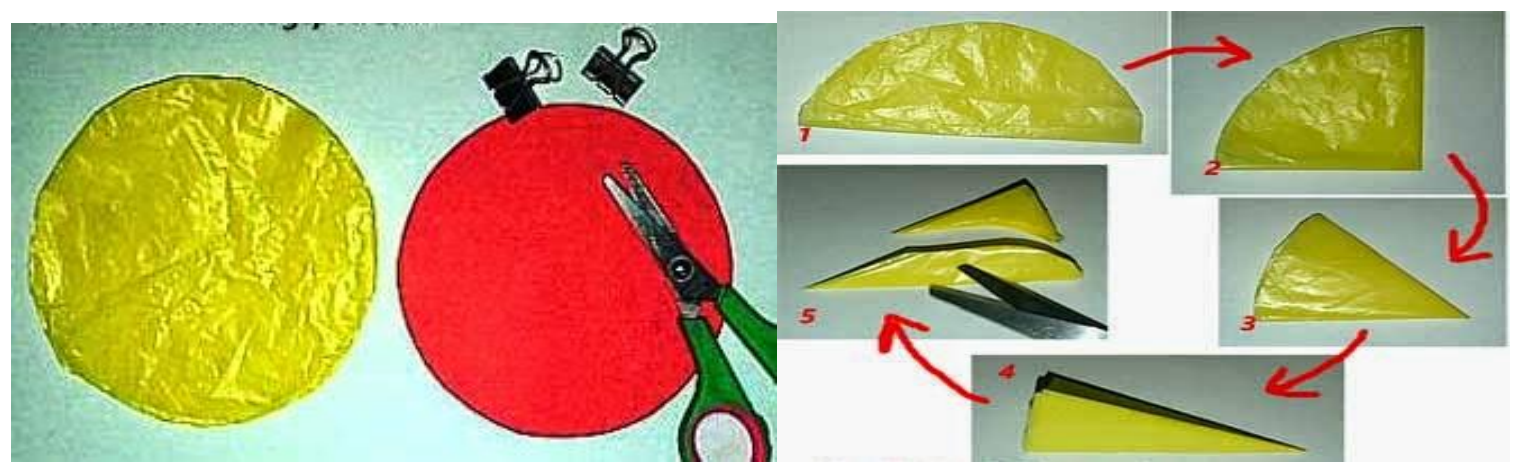

Gambar 3. Proses daur ulang plastik bekas tahap pertama

Selanjutnya buka lipatan yang telah digunting, hasilnya akan diperoleh bentuk dasar mahkota bunga dahlia dengan 8 lekukan. Siapkan lilin kemudian lipat mahkota berdasarkan diameter (sesuai dengan lipatan sebelumnya), bakar sisi lipatan (panaskan) di api lilin atau korek gas, sehingga terlihat sedikit menggumpal. Lakukan pada semua bagian bekas lipatan. Perhatikan garis merah pada gambar. Bagian merah tersebut adalah bagian mahkota yang akan dipanaskan. Pemanasan atau pembakaran ini bertujuan untuk membentuk mahkota menjadi sedikit menguncup (tidak datar), juga akan memberikan kekuatan dimana bekas api akan membentuk rangka bagi mahkota bunga dahlia. Sisihkan. Lakukan pembakaran pada sekitar 12 sampai 15 lembar mahkota. Selanjutnya nanti semua lembar akan digabungkan untuk membentuk sekuntum bunga. Kemudian membuat putik. Untuk membuatnya, siapkan selembar kantong plastik sisa membuat mahkota, dengan ukuran lebih kuran $7 \mathrm{~cm}$ x $8 \mathrm{~cm}$. Lipat beberapa kali sesuai lebarnya. Kemudian gunting-gunting dengan lebar sekitar 0,3 cm pada sisi-sisinya. Usahakan Jangan sampai ke tengah dan putus. Selanjutnya siapkan kawat ukuran sedang sepanjang lebih kurang $15 \mathrm{~cm}-17 \mathrm{~cm}$. Kemudian gulung calon putik bunga ini, lalu lilitkan pada kawat. Dapat menggunakan tang untuk memudahkan dalam melakukan pelipatan kawat. 


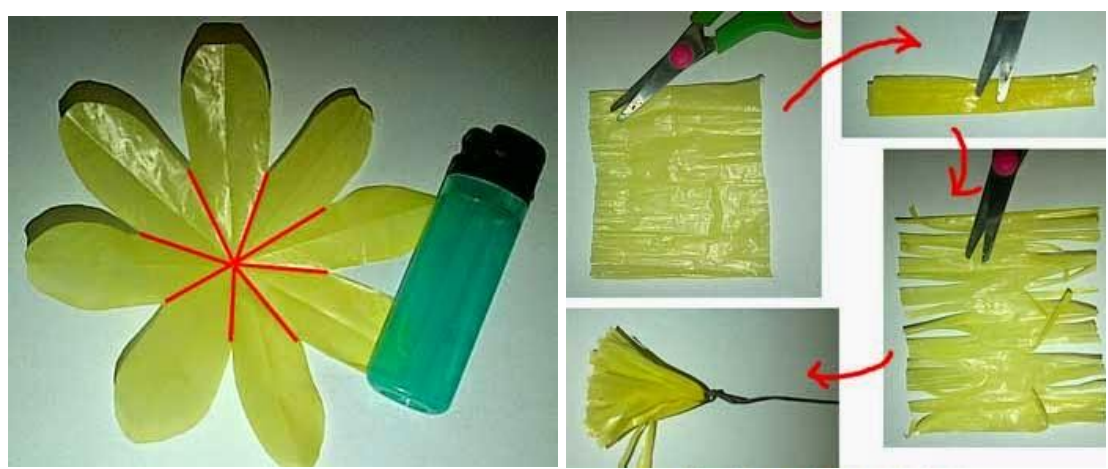

Gambar 4. Proses daur ulang pkastik bekas tahap kedua

Langkah berikutnya menyatukan putik dan tangkai dengan mahkota bunga. Caranya dengan menusukkan ujung kawat pada tengah-tengah mahkota. Geser dan rapatkan mahkota ke arah putih dengan sekuat mungkin. Siapkan sehelai plastik dengan lebar sekitar $3 \mathrm{~cm}$ dan panjang sekitar $15 \mathrm{~cm}$. Kemudian lilitkan pada dasar (bagian bawah mahkota) untuk mencegah mahkota bergeser-geser. Siapkan sehelai kantong plastik hijau ukuran kurang lebih $4 \mathrm{~cm} \times 20$ $\mathrm{cm}$. Plastik tersebut digunakan untuk melilit bagian dasar bunga dan tangkai untuk menutupi kawat. Tambahkan daun, dan bunga siap dirangkai di dalam vas untuk dipajang.

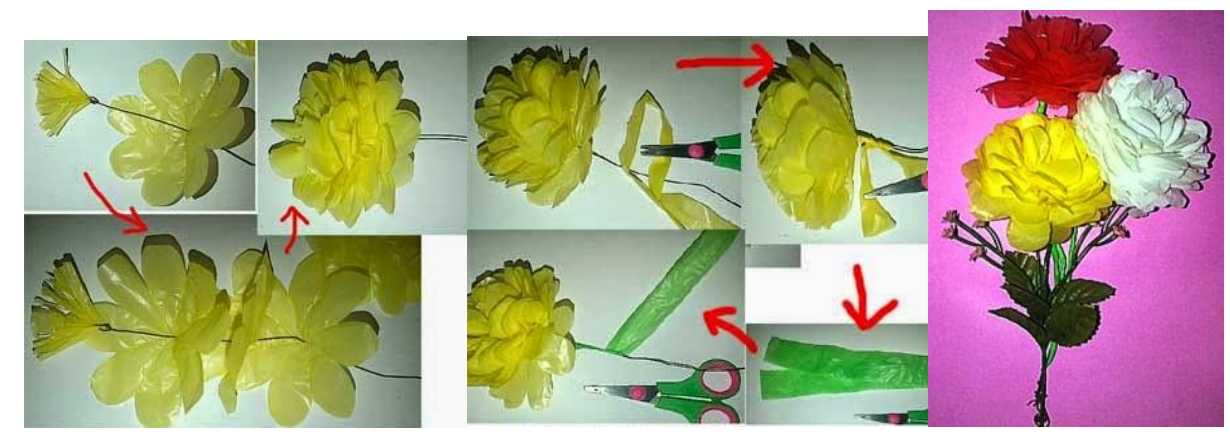

Gambar 5. Proses daur ulang plastik bekas tahap ketiga

\section{Hasil}

Proses pengolahan limbah plastik kresek bekas menjadi hiasan bunga cantik merupakan kreasi pengabdian yang dilakukan Universitas Pelita Bangsa untuk membantu masyarakat Desa Sukaresmi dalam proses daur ulang sampah plastik. Harapannya sampah plastik dianggap sebagai sumber daya yang dapat dimanfaatkan dibandingkan dianggap sebagai limbah yang tanpa nilai. Plastik kresek bekas yang susah terurai di alam dapat dijadikan suatu hasil karya yang dapat bertahan lama. Hal ini merupakan bagian dari tanggungjawab untuk melestarikan lingkungan.

\section{Kesimpulan}

Hasil dari pengabdian masyarakat ini dapat ditarik kesimpulan bahwa pengabdian Universitas Pelita Bangsa dapat memberikan pengaruh positif kepada masyarakat, hal ini dapat dilihat dari antusias masyarakat Desa Sukaresmi untuk mengikuti pelatihan daur ulang sampah plastik menjadi hiasan bunga yang bernilai ekonomi. Meningkatkan kerjasama antara Universitas Pelita Bangsa dengan masyarakat khususnya masyarakat Desa Sukaresmi sebagai perwujudan bukti pengabdian kepada masyarakat dan lingkungan. Meningkatkan ekonomi masyarakat dan mengurangi dampak negatif limbah plastik kresek bekas. Saran pengabdian 
selanjutnya adalah pemanfaatan yang lebih luas proses daur ulang sampah plastik kresek bekas dapat diolah menjadi beberapa produk tidak hanya hiasan bunga cantik saja, tetapi dapat dijadikan sebagai sumber energi serta lainnya.

\section{Daftar Pustaka}

Angraeni, Kamara, \& Dahlan. (2012). Sosialisasi Kimia Hijau Daur Ulang Limbah Organik dan Anorganik di Desa Padakembang dan Cilampung Hilir Kecamatan Cisayong Kabupaten Tasikmalaya. Jurnal Aplikasi IPTEK Untuk Masyarakat, 1(1), 49-56.

Hardianti, D., Abas, T., \& Ningsih, M. P. (2017). Persepsi Kader PKK Tentang Daur Ulang Limbah Plastik Berbasis Home Industri Di Desa Cilame Kabupaten Bandung Barat. Jurnal Family Edu, III(3), 73-79.

Linda, R. (2016). Pemberdayaan Ekonomi Kreatif Melalui Daur Ulang Sampah Plastik. Jurnal Al-Iqtishad, 1(12), 1-19.

Mahyudin, R. P. (2017). Kajian Permasalahan Pengelolaan Sampah Dan Dampak Lingkungan di Tempat Pemrosesan Akhir. Jurnal Teknik Lingkungan, 3(1), 66-74.

Permadi, G. (2011). Menyulap Sampah Jadi Rupiah. Surabaya: Mumtaz Media.

Putra, Y. H., Yuliana, I., \& Rahayu, Y. S. (2012). Pendampingan Kemitraan Pengelolaan Limbah Botol Plastik Menjadi Produk Bernilai Ekonomis Pada Masyarakat Desa Girimoyo Karangploso Malang. Prosiding Seminar Competitive Advantage, 1(2), 1-19.

Sirait, M. (2009). Sulap Sampah Plastik Lunak Jadi Jutaan Rupiah. Yogyakarta: B-Frist.

Sucipto, C. D. (2012). Teknologi Pengolahan Daur Ulang Sampah. Yogyakarta: Gosyen Publishing. 